\title{
O CULTO DO ARTIFÍCIO EM TRANSPOSIÇÕES DE ARTE NO ROMANCE ÀS AVESSAS, DE J.-K. HUYSMANS
}

\author{
Camila Marchesan Cargnelutti ${ }^{1}$ \\ Anselmo Peres Alós ${ }^{2}$
}

\begin{abstract}
Resumo: Em Às avessas (1884), encontra-se o principal exemplo da tentativa de Huysmans de renovação do romance, promovendo uma ruptura com os movimentos anteriores $e$, especialmente, com o naturalismo. O decadentismo encontrou em des Esseintes a principal representação das peculiaridades desse movimento, dentre elas, o culto do artifício. Em seu retiro, onde o personagem procura afastar-se do mundo real e deter-se em seus sonhos e imaginação, revela-se esse culto. Nesse estudo, investigaremos as transposições de arte em Às avessas, particularmente, as referentes aos quadros Salomé e A Aparição, de Moreau, de forma a analisar como se manifesta o culto ao artificial nessas passagens. Observamos que as transposições dessas obras privilegiam aspectos que remetem ao artificial e à beleza como produto do toque da arte sobre a natureza. Procuram ainda evocar as imagens representadas e explorar as possibilidades da literatura de sugerir e provocar sensações a partir da apreciação da arte pictural.
\end{abstract}

Palavras-chave: Artificio. Transposição de arte. Decadentismo. Às Avessas. Huysmans.

\section{SOBRE O DECADENTISMO E A ARTE FIN-DE-SIĖCLE}

Se a modernidade definida por Baudelaire já se anunciava em suas obras ainda em meados do século XIX, é a partir das décadas finais deste mesmo século que ela floresce na França e que começam a se levantar mais vozes sobre a temática, caracterizando o movimento conhecido como decadentismo. Tendo como representantes poetas, pintores, filósofos e escritores, tais como Verlaine, Moreau e Huysmans, o decadentismo distinguia-se, dentre outras peculiaridades, pela aversão ao mundo real, contaminado, na sua visão, pelo progresso, pelo positivismo, pelo cientificismo, pelo materialismo burguês e pelo desenvolvimento técnico e tecnológico. Desenvolvendo-se em uma conjuntura fin-de-siècle, marcada por mudanças aceleradas na sociedade francesa, que "parecia a ponto de mudar em essência, como já fizera em aparência", como definiu Eugen Weber (1988, p. 21), o movimento decadentista caracteriza-se por uma estética de negação e rejeição dessa realidade de transformações políticas, econômicas e sociais.

Nesse contexto de mudanças na França do final do século XIX, a noção de um tempo que chega ao fim traz também sentimentos pessimistas de decadência, diminuição e declínio (WEBER, 1988). Sobre essa época, a pesquisadora Fulvia

\footnotetext{
${ }^{1}$ Discente no Programa de Pós-Graduação em Letras - Mestrado em Estudos Literários da Universidade Federal de Santa Maria (UFSM). E-mail: camila.m.cargnelutti@gmail.com.

2 Docente no Programa de Pós-Graduação em Letras da Universidade Federal de Santa Maria (UFSM). Doutor em Letras pela Universidade Federal do Rio Grande do Sul (UFRGS). E-mail: anselmoperesalos@gmail.com.
} 
Moretto (1989, p. 14) também destaca, especialmente entre as elites, "uma vaga ideia de algo que morre, de um mundo em decomposição", bem como de uma espécie de "atmosfera de melancolia e desesperança" (ibid., p. 15). Em meio a esse clima de transformações científicas, tecnológicas e sociais, o decadentismo busca trilhar um caminho não só de negação, mas, especialmente, de reivindicação de uma nova forma de expressão estética e de uma renovação nos campos artístico e literário, de forma que a razão ceda espaço para o sonho, para a imaginação e para a fantasia.

Essa busca por inovação e renovação, por sua vez, tem na revolta direcionada ao naturalismo uma de suas principais formas de expressão, uma vez que se almeja a ruptura com esse movimento a qualquer preço. A sensação à época era, de acordo com Huysmans (1987), escritor francês que criou o romance $\grave{A} s$ avessas ${ }^{3}$ - que será analisado nesse estudo e que é considerado a "bíblia do decadentismo" - de que tudo, de alguma forma, já fora dito e que estavam todos reduzidos a "dar voltas por caminhos mais ou menos explorados" (ibid., p. 255). Conforme esclarece o próprio Huysmans que também fora discípulo de Émile Zola, mestre do movimento naturalista - em prefácio escrito vinte anos após a primeira publicação de As avessas:

\begin{abstract}
Havia muitas coisas que Zola não podia compreender: em primeiro lugar, a necessidade que eu experimentava de abrir as janelas, de fugir de um ambiente no qual sufocava; depois, o desejo que me tomava de sacudir os preconceitos, de romper os limites do romance, de nele introduzir a arte, a ciência, a história, de não mais usar essa forma, numa palavra, senão como um quadro onde inserir labores mais sérios. A mim, era isso que me preocupava nessa época, suprimir a intriga tradicional, inclusive a paixão, a mulher, concentrar o feixe de luz num único personagem, realizar o novo a qualquer preço (HUYSMANS, 1987, p. 268).
\end{abstract}

Dessa forma, o decadentismo, que recebeu influências também de outros movimentos, como a reapropriação da liberdade poética do romantismo, procurava encontrar formas de renovar a produção artística e literária francesa, reivindicando "uma nova estética e sobretudo um novo fazer" (MORETTO, 1989, p. 18). De acordo com a tentativa de definição desse movimento realizada por Moretto (1989), o decadentismo é uma espécie de novo lirismo que rejeita e procura substituir o naturalismo e o parnasianismo na França. Nesse sentido, na sociedade francesa fin-de-siècle, o movimento decadente "é a literatura e a arte que desenvolvem a imaginação, o sonho, que haviam desaparecido depois de Ronsard" (ibid., p. 30-31).

Baudelaire, considerado o poeta da modernidade e o ponto inicial do decadentismo, pregava a emancipação da arte sobre qualquer outra finalidade ou intenção, conforme explica Théophile Gautier (1989, p. 45-46): "Baudelaire desejava a absoluta autonomia da arte e não admitia que a poesia tivesse outra finalidade a não ser ela própria e outra missão além da de excitar na alma do leitor a sensação do belo, no sentido absoluto do termo". Ainda de acordo com Gautier (ibid., p. 42), a estética decadentista pode ser compreendida como "a arte em seu ponto de extrema maturidade a que as civilizações, ao envelhecerem, conduzem seus sóis oblíquos: estilo engenhoso, complicado, erudito, cheio de nuanças e rebuscado, recuando sempre os limites da língua".

\footnotetext{
${ }^{3}$ À rebours foi publicado pela primeira vez em 1884, na França.
}

CARGNELUTTI, Camila Marchesan; ALÓS, Anselmo Peres. 0 culto do artifício em transposições de arte no romance Às avessas, de J.-K. Huysmans. Crítica Cultural - Critic, Palhoça, SC, v. 9, n. 2, p. 283-293, jul./dez. 2014. 
Para Umberto Eco (2004), diante do mundo moderno, dos ideais positivistas e cientificistas, da industrialização das cidades e da ascensão da burguesia, o artista sentese simultaneamente ofendido e ameaçado pela realidade de sua época. Assim, resta ao artista, pertencente às classes mais abastadas da sociedade francesa, a valorização suprema da arte e da beleza, retirando-lhe quaisquer resquícios de documentação ou julgamento: "ganha forma uma verdadeira religião estética, e sob o lema da Arte pela Arte impõem-se a ideia de que a Beleza é um valor primário a ser realizado a qualquer custo, a tal ponto que muitos viverão a própria vida como obra de arte" (ECO, 2004, p. 330).

É o caso, por exemplo, dos dândis, como George Brummel e Oscar Wilde, que serviram de inspiração para a criação de diversos personagens na narrativa literária decadentista. O dândi, segundo Eco (ibid., p. 334) vê o ideal da Arte pela Arte como o "culto da própria vida pública, a ser 'trabalhada', modelada como uma obra de arte para se transformar num exemplo triunfante de Beleza. Não é a vida dedicada à arte, mas a arte aplicada à vida: a Vida como Arte". Sobre essa questão, Baudelaire (2009, p. 15) afirma que o dandismo "é uma espécie de culto de si mesmo", sendo o dândi uma figura "obcecada, acima de tudo, por distinção" que não admite a vulgaridade. Assim como Eco (2004), Baudelaire (2009, p. 16) também considera o dandismo como "uma espécie de religião".

Essa espécie de religião estética e o culto de si como obra de arte também estão relacionados à aversão e à recusa do mundo real, como é possível perceber em diversos trechos de Às avessas, como na passagem em que, através do narrador, descobrimos a profunda admiração de des Esseintes pelo poeta da modernidade, sendo significativa a escolha do poema em prosa de Baudelaire intitulado "Any where out of the world" para figurar em lugar de honra em seu gabinete. O mesmo local, aliás, em que o personagem fez questão de velar as vidraças das janelas, de modo a impedir a visão do lado externo da casa: "as vidraças, cujos vidros azulados [...] interceptavam a vista do campo e só deixavam penetrar uma luz falsa, foram veladas, por sua vez, por cortinados feitos de velhas estolas" (HUYSMANS, 1987, p. 48). Em outro excerto, de maneira ainda mais clara, é possível obervar novamente a aversão que des Esseintes nutre pela vida moderna: "distanciava-se cada vez mais da realidade e sobretudo do mundo contemporâneo pelo qual experimentava um horror crescente" (ibid., p. 211).

Conforme Melmoux-Montaubin (1996, p. 89), "a expressão mais comum da recusa do real reside na escolha de um exílio" . Nesse sentido, o autoexílio de des Esseintes em Às avessas e a tebaida modelada por ele são a representação, simultaneamente, de sua recusa do mundo - "pensando na nova existência que desejava organizar, experimentava uma alegria tanto mais viva quanto já se via à margem" (HUYSMANS, 1987, p. 40) - e de seu profundo desejo de isolar-se, de "mergulhar na definitiva quietude" (ibid., p. 39), de "desterrar-se na contemplação" e de "deter-se no sonho" (ibid., p. 247). Para Melmoux-Montaubin (1996, p. 90), o refúgio imaginado e

\footnotetext{
4 “Any where out of the world. - Não importa onde, fora do mundo” (HUYSMANS, 1987, p. 48).

${ }^{5}$ No original: "L'expression la plus commune du refus du rée, reside dans le choix d'une retraite loin du monde" (MELMOUX-MONTAUBIN, 1996, p. 89).
} 
projetado por des Esseintes funciona como "um espaço privilegiado, um microcosmo experimental onde se elaborariam as formas mais puras de esteticismo" nesse espaço à margem, dedicado ao esteticismo, à contemplação e ao sonho que se revela também o culto do artifício, outra característica fundamental do decadentismo e que será abordada ao longo dessa reflexão.

\title{
CULTO DO ARTIFÍCIO E DA BELEZA EM ÀS AVESSAS
}

Publicado pela primeira vez em 1884, Às avessas, do francês J.-K. Huymans, é um romance que subverte a forma e o conteúdo narrativo literário tradicional. Sem intriga, sem enredo, praticamente sem ação - os raros momentos nos quais há ação no romance são em recordações, memórias do protagonista, e não no presente da narrativa -, sem interação entre personagens, escrito como uma espécie de catálogo, de grande vitrina onde se expõem variados objetos, pedrarias, flores, perfumes, obras picturais e literárias, Huysmans desconstrói a narrativa usual com uma construção literária sem precedentes. Não sem razão, a obra tem sido estudada por diversos autores, que destacam a ruptura com os movimentos literários e artísticos anteriores, especialmente o naturalismo, e a suprema originalidade do escritor ao criar a obra considerada a "bíblia do decadentismo". Sobre essa questão, Umberto Eco (2004, p. 341) designa o livro como o "supra-sumo da sensibilidade decadente"; José Paulo Paes (1987, p. 28) o avalia como o "evangelho do esteticismo", e Mario Praz (1996, p. 283) o define como o "livro cardeal do decadentismo". Assim, o movimento decadentista encontraria na figura do célebre duque Jean Floressas des Esseintes, protagonista do romance Às avessas, a principal representação das características do movimento artístico e literário decadente e das particularidades dessa época de transição.

Dentre essas características e particularidades presentes em Às avessas, está o gosto e culto pelo artificial, que se revela também na obra baudelairiana tão admirada por des Esseintes, conforme explica Gautier (1989):

\begin{abstract}
Esta última frase $\mathrm{e}^{7}$ é característica e trai o gosto particular do poeta pelo artificial. Aliás, ele não escondia essa predileção. Comprazia-se nessa espécie de belo compósito e por vezes um pouco factício que elaboram as civilizações muito avançadas ou muito corrompidas. Digamos [...] que ele teria preferido, a uma simples moça tendo como único cosmético a água de sua bacia, uma mulher mais madura, que usasse todos os recursos de um sábio coquetismo, diante de um toucador coberto de frascos de essências, de leite virginal, de escovas de marfim e de grampos de aço (GAUTIER, 1989, p. 48, grifo do autor).
\end{abstract}

O fragmento supracitado exemplifica bem a preferência pelo artificial, não somente em Baudelaire, mas no movimento decadentista como um todo. A atração que o artificial exercia sobre os decadentistas, de acordo com Gautier (1989, p. 49), era

\footnotetext{
${ }^{6}$ No original: “[...] comme um espace privilegie, microcosme experimental dans requel s'elaborent les formes les plus pures de "esthétisme"” (MELMOUX-MONTAUBIN, 1996, p. 90).

${ }^{7} \mathrm{O}$ autor refere-se à frase escrita por Baudelaire em texto que precede a tradução do poema "O Corvo", de Poe: "É como a pintura nas faces de uma mulher naturalmente bela, um novo tempero para o espírito".
} 
resultante de sua representação como "retoques feitos pela arte sobre a natureza", o que, por sua vez, relaciona-se à valorização da "l'art pour l'art" e à concepção da literatura como intencional e não acidental. Sobre o gosto pelo artificial em Baudelaire, Gautier (1989, p. 50, grifo do autor), destaca que "convém citar como nota particular do poeta o sentimento do artificial. Com esta palavra é preciso compreender uma criação devida apenas à Arte e de onde a natureza está completamente ausente".

Dessa forma, a beleza afasta-se cada vez mais da natureza e aproxima-se da arte e do artifício, enquanto retoque da arte sobre a natureza produzindo o belo. Para Eco (2004, p. 340), “é nessa época - enquanto se perfila uma espécie de repúdio depreciativo em relação à natureza - que Beleza e Arte se fundem em uma dupla incindível. Não há Beleza que não seja obra de artifício, só o que é artificial pode ser belo". Pela lógica que move o decadentismo, a natureza não é capaz de produzir o belo, sendo necessária a intervenção da arte para tanto. Nesse sentido, a conclusão à que chegam os artistas do movimento decadentista é que a beleza de uma obra de arte é proporcional ao grau de artifício deliberado em sua criação: "é o decadentismo que, depois da afirmação de que a Beleza só se mostra como objeto de um longo e amoroso trabalho artesanal, chega à constatação de que uma experiência é tão mais preciosa quanto mais artificiosa for" (ECO, 2004, p. 340).

Em Às avessas, também é possível perceber a supremacia do artifício sobre a natureza, e da valorização da imaginação e do sonho em detrimento da realidade, como nos excertos abaixo:

\footnotetext{
O movimento lhe parecia, de resto, inútil, e a imaginação podia, no seu entender, facilmente substituir-se à realidade vulgar dos fatos. Reputava ser possível contentar os desejos tidos por mais difíceis de satisfazer na vida normal mediante um ligeiro subterfúgio, uma sofisticação aproximativa do objeto perseguido por eles (HUYSMANS, 1987, p. 52-53).

Tudo está em saber a pessoa arranjar-se, concentrar seu espírito num único ponto, abstrairse o suficiente para provocar a alucinação e poder substituir a realidade propriamente dita pelo sonho dela (HUYSMANS, 1987, p. 54).
}

Para des Esseintes, o artifício representava "a marca distintiva do gênio humano", e a natureza já tivera a sua vez e cansara a paciência dos espíritos refinados pela "desgastante uniformidade das suas paisagens e dos seus céus" (HUYSMANS, 1987, p. 54). O tempo da natureza findara: "não há dúvida de que essa sempiterna maçadora já esgotou a indulgente admiração dos verdadeiros artistas e é chegado o momento de substituí-la, tanto quanto possível, pelo artifício" (ibid.). Além dos fragmentos citados acima, na obra de Huysmans o culto ao artifício manifesta-se de diversas maneiras, como através de suas vestimentas extravagantes, de seus modos elegantes, de seus gostos literários e artísticos refinados, do cultivo de flores naturais que imitavam as artificiais, da decoração cuidadosa das peças de sua tebaida, como a sala de jantar a imitar a cabine de um navio - de modo a obter, "sem sair de casa, as sensações rápidas, quase instantâneas, de uma viagem de longo curso e esse gosto do deslocamento que só existe, em suma, na recordação, quase nunca no presente, no próprio instante em que se efetua" (HUYSMANS, 1987, p. 52). 
A clara preferência por imagens e viagens imaginadas (em detrimento das realizadas) relaciona-se, novamente, à exaltação do sonho, da imaginação e do artificial, essências do próprio movimento decadentista. Além disso, essa valorização, que evoca o culto ao artificial e à beleza como resultado alcançado por meio do artifício como retoque da arte sobre a natureza, demonstra também a tentativa de negação da realidade. Dessa forma, na narrativa de Huysmans, rejeitam-se também os ideais positivistas, o materialismo e a burguesia, que geravam aversão entre os decadentistas pelo temor permanente de que a técnica e o progresso acabassem suplantando o espaço dos sonhos e da arte na sociedade moderna.

Além da insatisfação com o mundo real, implícita na preferência pelo artificial, esta se relaciona ainda aos ímpetos idealistas de des Esseintes - "num dos seus momentos de auto-análise, des Esseintes enxerga nas 'suas tendências para o artifício' a manifestação de "ímpetos no rumo de um ideal, de um universo desconhecido" (PAES, 1987, p. 15). Por meio de diferentes manifestações ao longo da obra, o protagonista de Às avessas constrói, em suma, uma existência que pode ser classificada como "uma vida de sensações artificiais em um ambiente igualmente artificial” (ECO, 2004, p. 341). Essa procura constante de sensações e emoções pelo personagem, que se apresenta também como uma forma de fugir do tédio frequente, manifesta-se de diversas formas, desde a decoração da mansão, com a escolha cuidadosa das cores das paredes e das tapeçarias, até a reflexão crítica a respeito das obras picturais cuidadosamente escolhidas e admiradas que ornamentam seu gabinete.

\section{O ARTIFÍCIO EM TRANSPOSIÇÕES DE ARTE: SALOMÉ E A APARIÇÃO, DE MOREAU}

Historicamente, os campos artístico e literário desenvolveram complexas relações de interdependência e de interação (JURT, 2003). Nas décadas finais do século XIX, conforme explica o autor, os dois campos interagiam e alcançavam vantagens mútuas nessas relações: os críticos de arte literários contribuíam com os pintores agregando valor simbólico às suas obras de arte e, simultaneamente, convertiam a atividade crítica em valor literário, propagando muitas vezes a suposta supremacia da literatura sobre as demais artes. Além das reciprocidades entre as duas áreas, os pontos comuns também se revelavam no que se refere às teorias estéticas, às formas de expressão e às temáticas abordadas nas obras literárias e artísticas fin-de-siècle (JURT, 2003). O caso de Huysmans é um exemplo bastante característico dessa situação. Em seu romance $\grave{A s}$ avessas, o escritor francês reflete criticamente sobre diversas obras artísticas, dentre elas, as pinturas Salomé e A Aparição (ver imagens abaixo), de Gustave Moreau, construindo transposições de arte incorporadas à narrativa literária e essenciais para seu desenvolvimento. De acordo com Jurt (2003, p. 94), "para Huysmans, as críticas deveriam adotar a forma do poema em prosa, ou então se integrar na trama romanesca ${ }^{8 ،}$. A segunda alternativa proposta por Huysmans é a eleita para constituir o romance analisado, que apresenta diversas transposições de arte através do personagem des Esseintes.

\footnotetext{
8 No original: "pour Huysmans, les comptes rendus adopteront la forme du poème en prose, ou s'intégreront dans la trame romanesque" (JURT, 2003, p. 94).
} 
De acordo com Vieira (2013, p. 59), na transposição de arte "ao escritor cabia a tarefa de encontrar, com os meios próprios da língua, o que seria equivalente mais próximo do efeito estético proporcionado pela obra de arte inspiradora, obra que seria então recriada através dos meios de outra arte". Em seu estudo, Vieira analisa os discursos sobre arte produzidos pelo escritor brasileiro Gonzaga Duque e pelo francês Huysmans, com foco no romance Além" ${ }^{9}$ concluindo que "nem Huysmans nem Gonzaga Duque pretendem contar ou explicar a pintura. Os escritores simbolistas preferem a evocação de imagens que traduzem efeitos da obra plástica por intermédio de uma prosa rica em alusões" (VIEIRA, 2013, p. 70). Da mesma forma, as transposições de arte realizadas em Às avessas e, particularmente, as de Moreau aqui analisadas, não procuram explicar a obra pictural mas, antes, evocar imagens, descrever percepções e sugerir impressões a partir da observação da pintura. Como explica Vieira, "a transposição de arte simbolista é, antes de tudo, uma escrita da visão, da percepção e da representação de estados oníricos, místicos e alucinatórios despertados pela obra pictural", tendo como um de seus principais objetivos o "prolongamento das sensações experimentadas quando da observação das obras picturais" (VIEIRA, 2013, p. 71).

\section{FIGURA 1}
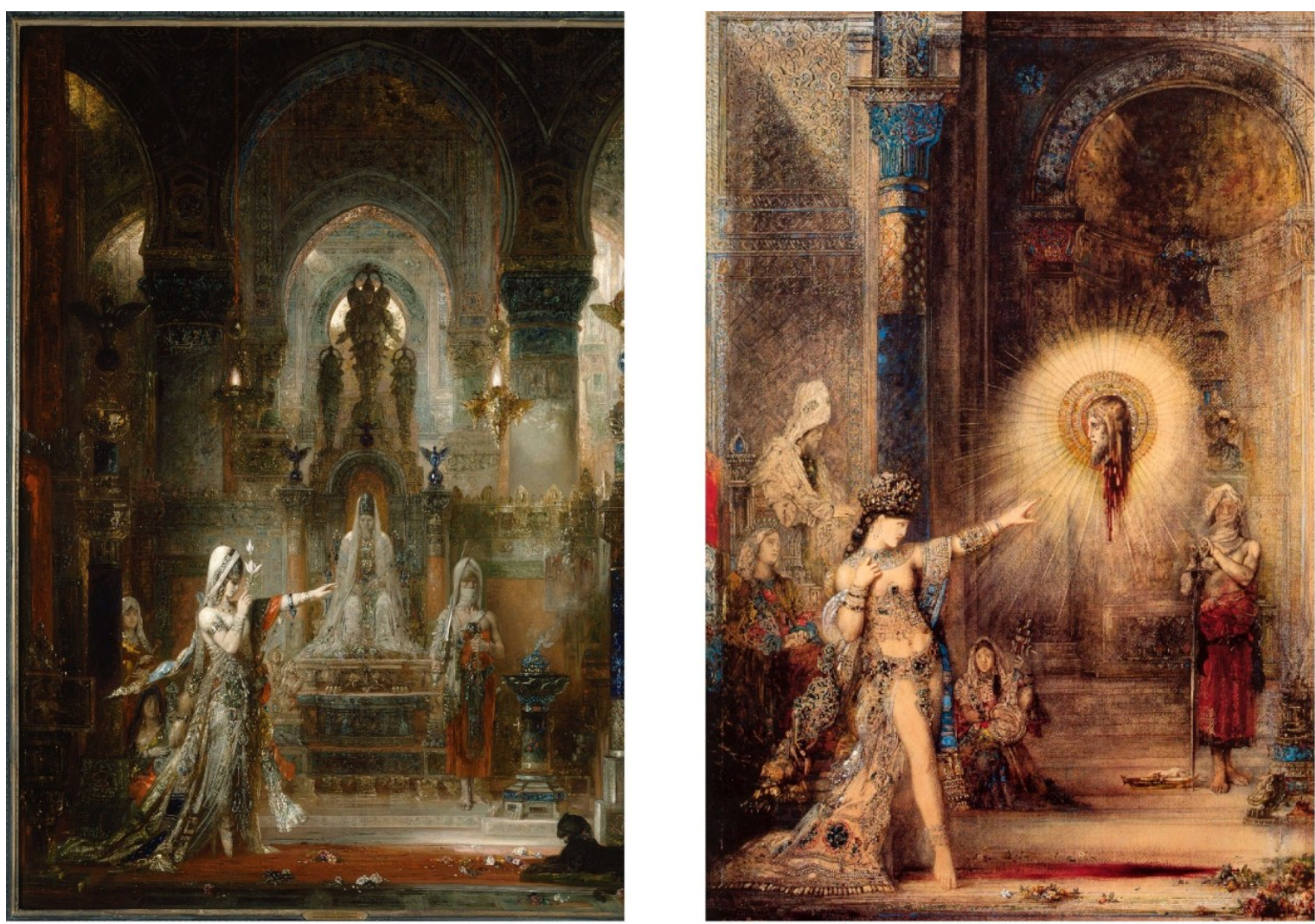

Legenda: Respectivamente, Salomé e A Aparição, de Gustave Moreau.

Fonte: http://www.wikiart.org/en/gustave-moreau/. Acesso em: 30 jun. 2014.

\footnotetext{
${ }^{9}$ Là-bas foi publicado pela primeira vez em 1891, na França.
}

CARGNELUTTI, Camila Marchesan; ALÓS, Anselmo Peres. 0 culto do artifício em transposições de arte no romance Às avessas, de J.-K. Huysmans. Crítica Cultural - Critic, Palhoça, SC, v. 9, n. 2, p. 283-293, jul./dez. 2014. 
Em Às avessas, as transposições de arte feitas por Huysmans através de des Esseintes evocam uma série de preceitos do movimento decadentista, como, por exemplo, a associação da mulher ao mal e ao pecado ${ }^{10}$ e a profunda admiração pelo artifício, temática de particular interesse nesse estudo. No romance, os quadros são descritos pelo olhar do protagonista, permitindo nossa visão da pintura a partir da visão de des Esseintes. Dessa forma, temos acesso, como leitores, a uma nova forma de conhecer o interior do protagonista, o que "colabora para o processo de conhecimento do caráter e da psicologia da personagem, que não mais se dá a ver pela óptica do narrador ou por suas relações sociais, mas pela arte e pelas sensações por ela despertadas" (VIEIRA, 2013, p. 60). Assim como des Esseintes cultuava o artifício em vários aspectos de sua vida, como visto anteriormente, pode-se perceber que, de certa forma, essa espécie de admiração e culto também se revela a partir das descrições que o personagem faz dos quadros de Moreau, nos quais se privilegiam os aspectos que remetem ao artificial, à intervenção da arte sobre a natureza de forma a criar beleza.

Um desses aspectos, que se sobressai na narrativa de Huysmans, pode ser observado na descrição de Salomé nas duas obras-primas de Gustave Moreau - "um artista cujo talento o arrebatava em longos transportes" (HUYSMANS, 1987, p. 83) que des Esseintes possui em seu gabinete: Salomé e A Aparição. Na transposição das obras do pintor, sobressai a evocação do fascínio que essa personagem bíblica consagrada na literatura e nas artes decadentistas - considerada a própria "deusa da decadência" - exerce sobre des Esseintes. No entanto, ressaltamos, esse fascínio está relacionado, principalmente, a dois aspectos em Salomé - sua representação como encarnação do mal, do inquietante e da corrupção e a admiração de sua beleza enquanto "mulher joia" ou mulher vestida de joias, associando sua beleza a um modelo artificial, uma vez que, segundo os preceitos do movimento decadente, somente com retoques do artifício seria possível criar o belo (ECO, 2004).

\begin{abstract}
[...] seus seios ondulam e, roçados pelos colares que turbilhonam, ficam de bicos eretos; sobre a pele úmida, os diamantes presos cintilam; seus braceletes, seus cintos, seus anéis lançam faúlhas; sobre a túnica triunfal, recamada de pérolas, ornada com ramagens de prata, guarnecida de palhetas de ouro, a couraça de ourivesaria em que cada malha é uma pedra entra em combustão (HUYSMANS, 1987, p. 84-85, grifos nossos).

Ela está quase nua; no ardor da dança, os véus se desataram, os brocados escorregaram; está vestida tão-só de materiais de ourives e de minerais lúcidos; um gorjal lhe aperta o talhe qual fosse um corpete e, à semelhança de broche soberbo, uma joia maravilhosa dardeja clarões na ranhura dos seus dois seios; mais abaixo, nas ancas, o cinto que a rodeia cobre-lhe a parte superior das coxas sobre as quais pende um gigantesco pingente de onde flui um rio de rubis e de esmeraldas; por fim, sobre o corpo desnudo, entre o gorjal e o cinto, o ventre convexo, escavado pelo umbigo cujo orifício parece um sinete gravado em ônix, de tons leitosos e cores róseas (HUYSMANS, 1987, p. 88, grifos nossos).
\end{abstract}

O fascínio exercido pela representação de Salomé como mulher joia, vestida de pedras preciosas, é o que particularmente interessa aqui e pode ser exemplificado pelas descrições de Salomé acima, respectivamente do quadro a óleo Salomé e da aquarela $A$ Aparição, ambos remetendo à atração por essa mulher pelo fato de ela representar

\footnotetext{
${ }^{10}$ Simone de Beauvoir compõe um extenso trabalho crítico a essas concepções, relacionadas à construção história e social da mulher como 'o outro', em sua obra "O segundo sexo", publicado originalmente em 1949.
}

CARGNELUTTI, Camila Marchesan; ALÓS, Anselmo Peres. 0 culto do artifício em transposições de arte no romance Às avessas, de J.-K. Huysmans. Crítica Cultural - Critic, Palhoça, SC, v. 9, n. 2, p. 283-293, jul./dez. 2014. 
simbolicamente um padrão artificial. Conforme explica Eco (2004, p. 342), "quando se deseja a mulher [...] ama-se na feminilidade a natureza alterada"; assim, no caso de $\grave{A s}$ avessas, des Esseintes fascina-se por essa mulher joia, ornamentada e vestida de pedrarias, "que só pode ser vista em todo o seu fascínio quando remetida a um modelo artificial" (ECO, 2004, p. 342). Nesse sentido, pode-se dizer que a beleza feminina apreciada em Salomé por des Esseintes representa uma beleza não natural, mas retocada pela arte e pelo artifício.

Nas transposições de arte em Às avessas, além da atração de des Esseintes pela mulher vestida de joias preciosas e pela beleza fruto do artifício, pode-se perceber aspectos do culto do artifício também na representação hierática das Salomés de Moreau. Por meio dessa estratégia, as descrições das obras picturais evocam, através de termos que associam Salomé à inércia, à rigidez, à insensibilidade e à imobilidade, imagens de um ser, não só inatingível, mas também não natural - artificial - como no trecho: "na estátua insensível e impiedosa, no inocente e perigoso ídolo, o erotismo, o terror do ser humano amanhecera; [...] um horrendo pesadelo estrangulava agora a histriã extasiada pelo rodopio da dança, a cortesã petrificada, hipnotizada pelo horror" (HUYSMANS, 1987, p. 89, grifos nossos).

Outra característica do decadentismo, de acordo com Moretto (1989, p. 32), é o "fascínio pelas arquetípicas lendas antigas e medievais" e o "gosto pela natureza petrificada e fria dos bizantinos", também representados pelo motivo Salomé e pela descrição do espaço e da arquitetura dos lugares dos quadros de Moreau, como no fragmento referente à descrição de Salomé: "um trono se erguia, semelhante ao altarmor de uma catedral, sob inúmeras abóbadas apoiadas em colunas atarracadas bem como em pilares romanos, [...] num palácio parecido a uma basílica, de arquitetura a um só tempo muçulmana e bizantina" (HUYSMANS, 1987, p. 83-84). Em Às avessas, além do fascínio pelas lendas antigas e pela civilização bizantina e sua "natureza petrificada e fria", a presença da lenda bíblica que inspirou fortemente a produção finde-siècle relaciona-se também à recusa do mundo contemporâneo e esta, como visto anteriormente, está associada à valorização do artifício como uma forma de descobrir novas sensações e de mergulhar em outras "realidades", feitas de sonhos e fantasias.

Por último, o artifício nas transposições de arte em Às avessas é reforçado pelo próprio caráter da pintura de Gustave Moreau, pela sua capacidade de criação de um universo onírico e de transportar para esse mundo de sonhos e de irrealidade os admiradores de suas obras. O duque des Esseintes é um desses admiradores que, na sua permanente busca por sensações, enxerga nas pinturas de Moreau a possibilidade de "viajar" através da arte por um mundo imaginário, irreal, artificial: "quisera [...] algumas obras sugestivas que o transportassem a um mundo desconhecido, desvendando-lhe os rastros de novas conjecturas, sacudindo-lhe o sistema nervoso com histerias eruditas, pesadelos complicados, visões lânguidas e atrozes" (ibid., p. 83). Moreau, para des Esseintes, é, dentre todos os artistas, aquele que o arrebata em longos transportes por meio do seu talento artístico, aquele que o faz sonhar por noites a fio diante das duas obras adquiridas e o único artista que realmente conseguiu exprimir em suas pinturas a Salomé que ele, des Esseintes, imaginava - um misto de "inquietante exaltação da dançarina" com a "refinada grandeza da assassina", a "Salomé sobrehumana e estranha que havia sonhado" (ibid., p. 85). 
Em Às avessas, encontra-se o principal exemplo da tentativa de Huysmans de renovação do romance, promovendo uma ruptura com os movimentos anteriores e, especialmente, com o naturalismo. Tanto na concepção quanto na escritura dessa obra, fica implícita a preocupação do autor em pensar a modernidade. O decadentismo encontrou na figura do duque des Esseintes a principal representação das peculiaridades desse movimento e dessa época fin-de-siècle, dentre elas, como se procurou demonstrar ao longo desse estudo, o culto do artifício, uma característica essencial dos artistas e escritores decadentistas. É em seu retiro, em seu espaço reservado e à margem da sociedade moderna francesa do final do século XIX, onde o personagem procura abstrair-se do mundo real, isolar-se em estados de contemplação e deter-se em seus próprios sonhos e imaginação, que se revela essa espécie de culto ao artifício. Como visto, essa característica decadentista permeia todo o romance e surge de diversas formas por meio do protagonista, através, por exemplo, da minuciosa escolha das flores verdadeiras - mas que parecem falsas - e das transposições de arte presentes ao longo da obra.

As transposições de arte construídas em $\grave{A}$ s avessas privilegiam certos aspectos que remetem ao artificial e à beleza como produtos do retoque e intervenção da arte sobre a natureza, tais como o fascínio por Salomé, apreciada justamente por representar uma beleza retocada pela arte e pelo artifício, e sua representação hierática, sugerindo imagens de um ser, não somente inatingível mas, principalmente, não natural, artificial. Além disso, nas transposições de arte de Moreau realizadas através da crítica literária incorporada à narrativa, particularmente, é possível perceber que, mais do que simplesmente descrever as obras, Huysmans, por intermédio de des Esseintes, procura evocar as imagens representadas e as percepções e impressões sentidas durante sua apreciação, explorando também as possibilidades da arte literária de sugerir e provocar sensações e emoções, tendo como ponto de partida a observação da arte pictural.

\section{REFERÊNCIAS}

BAUDELAIRE, Charles. O dândi. In: BALZAC, Honoré de; BAUDELAIRE, Charles. Manual do dândi: a vida com estilo. Belo Horizonte: Autêntica Editoria, 2009. p. 11-20.

ECO, Umberto. A religião da beleza. In: ECO, Umberto. História da beleza. Rio de Janeiro: Record, 2004. p. 329-359.

GAUTIER, Théophile. Prefácio às Flores do Mal. In: MORETTO, Fulvia M. L. (org.). Caminhos do decadentismo francês. São Paulo: Editora da Universidade de São Paulo / Editora Perspectiva, 1989. p. 41-51.

HUYSMANS, J.-K. Às avessas. Tradução de José Paulo Paes. São Paulo: Companhia das Letras, 1987.

HUYSMANS, J.-K. Prefácio escrito vinte anos depois do romance. In: HUYSMANS, J.-K. Às avessas. Tradução de José Paulo Paes. São Paulo: Companhia das Letras, 1987. p. 255-273.

JURT, Joseph. Campo literário e campo artístico na França (1880-1900). Tradução de André Soares Vieira. Terceira Margem. Programa de Pós-Graduação em Ciência da Literatura, UFRJ, Rio de Janeiro, Ano VII, n. 8, 2003, p. 82-102. Disponível em

$<$ http://www.ciencialit.letras.ufrj.br/terceiramargemonline/numero08/NUM08_2003.pdf $>$. Acesso em 16 jun. 2014.

CARGNELUTTI, Camila Marchesan; ALÓS, Anselmo Peres. 0 culto do artifício em transposições de arte no romance Às avessas, de J.-K. Huysmans. Crítica Cultural - Critic, Palhoça, SC, v. 9, n. 2, p. 283-293, jul./dez. 2014. 
MELMOUX-MONTAUBIN, Marie-Françoise. L'esthète fin-de-siècle: l'oeuvre interdite. Romantisme, 1996, n. 91, p. 89-98.

MORETTO, Fulvia M. L. (org.). Caminhos do decadentismo francês. São Paulo: Editora da Universidade de São Paulo / Editora Perspectiva, 1989.

PAES, José Paulo. Huysmans ou a nevrose no novo. In: HUYSMANS, J.-K. Às avessas. Tradução de José Paulo Paes. São Paulo: Companhia das Letras, 1987. p. 5-28.

PRAZ, Mario. A Carne, a morte e o diabo na literatura romântica. Tradução de Philadelpho Menezes. Campinas, SP: Editora da Unicamp, 1996.

VIEIRA, André Soares. Huysmans e Gonzaga Duque: transposições de arte em textos franceses e brasileiros do Simbolismo. In: Aletria, n. 13, v. 23, set./dez. 2013. p. 59-72.

WEBER, Eugen. França fin-de-siècle. São Paulo: Companhia das Letras, 1988.

\section{Recebido em 02/08/2014. Aprovado em 10/11/2014.}

Title: The cult of artifice in transpositions of art in the novel À rebours, by J.-K. Huysmans Abstract: In À rebours (1884) lies the prime example of Huysmans' attempt to renew the novel, promoting a break with previous movements, and especially with Naturalism. The Decadent movement found in des Esseintes the core representation of its own peculiarities, among which, the cult of artifice. In Esseintes' reclusion, where he seeks shelter from the real world and tries to dwell in his dreams and imagination, the character's cult of artifice is revealed. In this study, we examine the transpositions of art in A rebours, particularly those relating to Moreau's paintings Salomé and The Apparition, in order to analyze how the cult of artifice manifests itself in these excerpts. The transpositions of these works emphasize aspects that refer to the artificial as well as the beauty, both as products of art's touch over nature. They also attempt to evoke the represented images and explore the possibilities of literature to suggest and provoke sensations from the appreciation of pictorial art.

Keywords: Artifice. Transposition of art. Decadent movement. À rebours. Huysmans.

CARGNELUTTI, Camila Marchesan; ALÓS, Anselmo Peres. O culto do artifício em transposições de arte no romance Às avessas, de J.-K. Huysmans. Crítica Cultural - Critic, Palhoça, SC, v. 9, n. 2, p. 283-293, jul./dez. 2014. 
